\title{
Determining Incentive in Support of Plastic Recycling Industry in Indonesia
}

\author{
Sekarayu Rahmadiani*, Wulandari Kartika Sari \\ Dept. of Fiscal Administration \\ University of Indonesia \\ Depok, Indonesia \\ *sekar.rahmadiani@gmail.com,ks.wulandari87@gmail.com
}

\begin{abstract}
Plastic is an inorganic waste that is difficult to decompose, thus causing pollution. In Indonesia, plastic is the second largest type of waste produced. There are various ways that can be done to overcome the plastic waste problem in Indonesia, one of them being recycling. However, there are several factors that influence the development of the plastic recycling industry in Indonesia, tax being one of them. The Indonesian Plastic Recycling Association stated that tax, specifically the imposition of $10 \%$ VAT is one of the inhibiting factors for the development of the plastic recycling industry. Therefore, this research aims to determine the form of incentive that can be given to support the plastic recycling industry in Indonesia. The method used in this research is qualitative approach and descriptive research type which conducted from February to July 2020. There are various forms of incentives that already exists in Indonesia according to Act 42 the Year 2009. These incentives exist in the forms of Exempted VAT and noncollected VAT. To obtain incentive, there are various conditions that must be met by the plastic recycling industry. The result of this research shows that the form of incentive that can be given to the plastic recycling industry is non-collected VAT.
\end{abstract}

Keywords—value added tax, tax incentive, plastic recycling

\section{INTRODUCTION}

The problem regarding waste is a universal problem that affects everyone in the world. Poorly managed waste can clog waterways, transmit disease, and pollute the oceans. Currently, the world produces 2.01 billion tons of waste every year. World Bank research in 2018 shows that the Indonesian people produce $0.68 \mathrm{~kg}$ of waste per person everyday [1]. In addition, World Bank research also shows that plastic is one of the largest type of waste produced in Indonesia, only second behind organic waste [2]. Different from the organic waste, plastic is an inorganic waste that is difficult to decompose, thus causing pollution.

During the COVID-19 pandemic, Indonesia experiences a surge in plastic waste. The cause of this spike is the increased use of plastic in food delivery services and online shopping during this pandemic [3]. The increase in plastic waste needs to be addressed so that it won't cause further pollution. Recycling is one of the most important measures currently available to reduce the impact of damage from plastic waste. Recycling provides opportunities to reduce oil, carbon dioxide emissions and the amount of waste that needs to be disposed of. Plastic recycling is one method that can be used to reduce environmental impact and depletion of resources. Thus, recycling can result in increased environmental efficiency [4].

Recycling is the best solution to manage plastic waste because it limits environmental impact and generates significant socio-economic benefits [5]. By recycling plastic, the plastic waste produced can be reused. Plastic recycling is a part of circular economy which is a restorative and regenerative concept that aims to eliminate waste [6].

The population of plastic recycling industry in Indonesia consists of 600 large companies and 700 small companies with a production capacity of 2.3 million tons per year and an investment of up to Rp7.15 trillion [7]. To be able to carry out production activities, there are several stages in the plastic recycling industry. Some of the steps carried out by waste collectors or banks, collectors, grinders, processors, converters, and wholesalers.

Business activities carried out by plastic recyclers lead to taxation, one of which is Value Added Tax (VAT). In accordance with Act Number 42 the Year 2009, VAT is charged at a rate of $10 \%$. The Indonesian Plastic Recycling Association (ADUPI) stated that the imposition of $10 \%$ VAT affects the interest and competitiveness in the plastic recycling industry, thus making it an inhibiting factor for the development of the plastic recycling industry in Indonesia. ADUPI stated that providing incentives for the plastic recycling industry could help develop the plastic recycling industry in Indonesia. The form of incentive that ADUPI wants is a reduction in VAT rates or an exemption from VAT [8].

However, tax incentives cannot be given immediately. In order to provide tax incentives, it is necessary to conduct a study first in which this research aims to determine the form of incentive that can be given to support the plastic recycling industry in Indonesia. 


\section{METHODS}

This research was conducted with a qualitative approach. The qualitative data collection was carried out through field and literature studies. The field study was done to obtain primary data by conducting in-depth interview with various informants consisting plastic recycling business actors, Ministry of Industry, Directorate General of Tax, and tax academic. The literature study was done to obtain secondary data. The result of both studies were analyzed to be presented in the form of result discussion and conclusion to answer the research question. This research was carried out from February to July 2020.

\section{RESULTS AND DISCUSSION}

\section{A. Determinant Factors}

The development of the plastic recycling industry is influenced by several factors which are studied in to support further analysis. First, the industry has strength in the form of indirect incentive in the form of exempted VAT on imported machines as regulated in Government Regulation Number 81 the Year 2015. In addition, the strength of the plastic recycling industry is support from the government for the industry as a solution to reducing imports of plastic raw materials.

Other factor that influences the development of the plastic recycling industry are weaknesses in the form of $10 \%$ of VAT imposition and lack of raw materials $[7,8]$. However, there is an opportunity where there is a discourse about providing incentives for the plastic recycling industry [9]. Lastly, there is a threat to the plastic recycling industry in the form of excise taxation which can reduce the availability of raw materials even further [8].

\section{B. Fiscal Incentive}

Plastic recyclers stated that tax is one of the factor hindering its industrial development. Thus, the plastic recyclers asked for VAT incentives so that the interest in plastic recycling would increase. In some cases, tax incentives can be a more effective way of achieving policy objectives [10].

Under legal provisions, tax incentive will be a special provision given to eligible investment project. However, effectively, tax incentives will become a special tax provision provided to reduce the size of the effective tax burden [11]

The provision of incentives will help the survival of the plastic recycling industry where tax incentives are a means to increase certain goals [12], which in this case is the development of the plastic recycling industry. Explanation of Article 16B Act Number 42 the Year 2009 provide an explanation of the criteria for industries that are entitled to incentives, which is "...provide tax facilities that are really needed, especially for the success of the high priority sector of economic activity on national scale, encourage the development of the business world and increase competitiveness, support national defense, and facilitate national development." [13].
The investment value of the plastic recycling sector itself has reached Rp7.15 trillion where the plastic recycling industry creates added value of more than Rp10 trillion per year and the realization of the export of plastic recycled derivative products in 2019 reached USD141.9 million [7]. It can be said that the plastic recycling industry has the potential to support investment value in its sector. With a high investment value, the recycling industry can be deemed to have met the criteria as stated in the Explanation of Article 16B Act Number 42 the Year 2009.

The plastic recycling party itself asked for incentives in the form of rate reduction or Exempted VAT. This research will further analyze what kind of incentives can be given to the plastic recycling industry based on the forms of incentives that already exist in Indonesia.

\section{- Rate Reduction}

It was previously stated that the plastic recycling party asked for incentive in the form of a VAT rate reduction or exemption. The VAT rate is regulated in Article 7 paragraph (1) Act Number 42 the Year 2009 at $10 \%$, which in paragraph (3) states that "The tax rate as referred to in paragraph (1) can be changed to be a minimum of $5 \%$ and a maximum of $15 \%$ whose rate changes are regulated by a Government Regulation." [13].

Even though Article 7 paragraph (3) Act Number 42 the Year 2009 states that the tax rate can be changed to a minimum of 5\%, VAT rate applied in Indonesia has adopted a single rate, namely the VAT rate of $10 \%$. Thus, it can be concluded that with the implementation of single rate, incentive in the form of rate reduction is difficult to realize. Apart from implementation of single rate, there is still no Government Regulation governing the VAT rate reduction policy [14]

\section{- Exempted VAT and Non-collected VAT}

Referring to Article 16B Act Number 2009 the Year 2009, there are two forms of incentives that can be given for VAT, namely non-collected VAT and exempted VAT. To obtain this incentive, at least one of the five criteria listed in Article 16B paragraph (1) must be fulfilled. Of the five criteria, the criteria that can be met by the plastic recycling industry is the second criteria, namely the submission of certain Taxable Good or Taxable Service. The reason of fulfillment for this criteria is that the plastic recycling industry goods can be categorized as strategic goods which have uses in people's daily lives.

The difference between non-collected VAT and exempted VAT is found in the Input Tax crediting mechanism. Input Tax for non-collected Taxable Good and / or Taxable Service can be credited whereas Input Tax for exempted Taxable Good and Taxable Service cannot be credited. 
TABLE I. CREDITING MECHANISM

\begin{tabular}{|l|l|l|}
\hline \multirow{2}{*}{} & \multicolumn{2}{|c|}{ Incentives } \\
\cline { 2 - 3 } & \multicolumn{1}{|c|}{ Exempted VAT (in Rp) } & Non-Collected VAT (in Rp) \\
\hline $\begin{array}{l}\text { Taxable } \\
\text { Good }\end{array}$ & 10.000 .000 & 10.000 .000 \\
\hline $\begin{array}{l}\text { Output } \\
\text { Tax (OT) }\end{array}$ & - & $\begin{array}{l}1.000 .000 \quad \text { (non-collected } \\
\text { VAT, therefore it's } \\
\text { considered 0) }\end{array}$ \\
\hline $\begin{array}{l}\text { Input Tax } \\
\text { (IT) }\end{array}$ & 500.000 & 500.000 \\
\hline $\begin{array}{l}\text { VAT } \\
\text { Payable }\end{array}$ & $\begin{array}{l}\text { The IT can't be credited, } \\
\text { likely the IT of 500.000 } \\
\text { will be charged as a cost } \\
\text { by the seller }\end{array}$ & $\begin{array}{l}0-500.000=(500.000) / \\
\text { Overpayment }\end{array}$ \\
\hline
\end{tabular}

It can be seen in Table I that the Input Tax for the noncollected VAT can be credited whereas Input Tax for the exempted VAT cannot be credited. In the crediting of the exempted VAT, if the Input Tax is charged to the cost, then the Cost of Goods Sold will increase so that the seller's operating profit will decrease. The imposition of Input Tax in these costs can also cause the selling price to increase to maintain profit, unless the entrepreneur wants to lose money [8]. Therefore, if the Taxable Good submission is exempted from the imposition of VAT, the longer the business chain is, the Input Tax will accumulate in the Cost of Goods Sold and cause the selling price of goods in the next chain to increase [14].

If the plastic recycling party ask for incentive for the entire business chain, it would be better for the incentive to be given in the form of non-collected VAT compared to exempted VAT. Exemption from VAT will cause price accumulation or increase without the neutrality of the Input Tax crediting so that the competitiveness of business actors will also be affected. In contrast to exempted VAT, non-collected VAT provides neutrality by allowing Input Tax crediting. A further illustration of the impact of exempted VAT can be seen in Table II.

TABLE II. IMPACT OF EXEMPTED VAT

\begin{tabular}{|l|c|c|}
\hline & Decrease in Profit (in Rp) & $\begin{array}{c}\text { Increase in the Price of } \\
\text { Goods (in Rp) }\end{array}$ \\
\hline $\begin{array}{l}\text { Selling } \\
\text { Price of } \\
\text { Goods }\end{array}$ & 10.000 .000 & 10.500 .000 \\
\hline Cost (+IT) & 5.500 .000 & 5.500 .000 \\
\hline $\begin{array}{l}\text { Operating } \\
\text { Profit }\end{array}$ & 4.500 .000 & 5.000 .000 \\
\hline
\end{tabular}

The illustration in Table II shows that the impact of charging Input Tax to costs will lead to a decrease in profit or an increase in selling prices. In contracts to the exempted VAT, crediting the Input Tax in non-collected VAT is allowed. If the sale is solely related to plastic recycling, then the non-collected VAT option will result in an Overpayment position as shown in Table I. The Overpayment is compensated for the next tax period as stated in Article 9 paragraph (4) Act Number 42 the Year 2009. Furthermore, in Article 9 paragraph (4a) it is stated that the overpayment can be submitted for a refund at the end of the financial year or restitution. To get a restitution, the Directorate General of Taxes will conduct an inspection.

However, if you experience Overpayment every month, the company's cash flow will be affected so that policies such as faster payment return will be needed, such as Regulation of the Minister of Finance Number 117/2019. Based on Article 13 paragraph (2), plastic recycling industry is not included in the criteria for the right to receive preliminary refunds of tax overpayments.

It should be noted that providing incentives can cause a potential loss from VAT revenues. With the provision of incentives, VAT receipts will be reduced because goods that were previously subjected to VAT after being given incentives are no longer subjected to VAT. In addition to potential loss, the provision of VAT incentives will also increase the responsibility for supervision and administrative provision related to the effectiveness of the incentives for the Directorate General of Taxes. Moreover, it is necessary to monitor that the incentive provided is only used by recycling entrepreneurs and not by virgin material entrepreneurs.

\section{Non Fiscal Incentive}

One of determinant factor that influence the development of plastic recycling industry in Indonesia is the lack of raw materials. One of the reasons for the lack of raw materials is that not all plastic waste is being recycled. There are two types of plastic waste, which are recyclable and recyclability. Until now, only recyclable plastic waste is recycled [15].

To overcome the problem of lack of raw materials, the incentive that can be given is Extended Producer Responsibility (EPR). EPR is a policy approach whereby producers are given significant responsibility, both financially and physically, for the care and disposal of post-consumer products. Assigning such responsibilities can in principle provide incentives to prevent waste at source, promote product design for the environment and support achieving public recycling [16].

Countries that have successfully implemented EPR are European countries, one of which is Norway. The EPR scheme used by Norway is a Reverse Vending Machines scheme. Citizens can exchange their purchased bottles into several thousand Reverse Vending Machines as well as in shops for exchange of cash or store credit. To ensure the return of the bottle, the government places a deposit of 15 to 30 cents which will be redeemed when the bottle is returned. If the initial incentive is not sufficient, the Norwegian government has imposed an Environmental Tax on plastic producers where the tax can be reduced when the plastic producers recycle their products more [17].

The government has issued the Minister of Environment and Forestry Regulation Number P.75/MENLHK/SETJEN/ KUM.1/10/2019 which has the essence of EPR. In the regulation, it is regulated so that plastic producers to use 
recyclable material, thus can provide materials for the plastic recycling industry. However, this regulation has not been properly implemented in Indonesia [15].

\section{CONCLUSION}

Recycling can be done to overcome the plastic waste problem in Indonesia. However, the plastic recycling party felt that the imposition of $10 \%$ VAT is an inhibiting factor for industrial development, therefore they asked for an incentive. Providing incentive in the form of rate reduction is difficult to realize because of the implementation of single rate in Indonesia. Incentive that can be given to the plastic recycling industry is non-collected VAT because it provides neutrality in the Input Tax crediting mechanism which is not provided in Exempted VAT.

\section{REFERENCES}

[1] S. Kaza, L. Yao, P. Bhada-Tata and F. Woerden, What a Waste 2.0 : A Global Snapshot of Solid Waste Management to 2050, The World Bank, 2018.

[2] World Bank, "Sampah Laut Indonesia," Laporan Sintesis, 2018.

[3] R. K. Dewi, "Mengapa Pandemi Corona Picu Lonjakan Limbah Plastik di Asia Tenggara?," 2020. [Online]. Available: https://www.kompas.com/tren/read/2020/08/10/070000165/mengapapandemi-corona-picu-lonjakan-limbah-plastik-di-asiatenggara?page $=$ all.

[4] J. Hopewell, R. Dvorak and E. Kosior, "Plastic Recycling: Challenges and Opportunities," Journal Philos Trans R Soc Lond B Biol Sci, 2009.
[5] W. d'Ambrieres, "Plastic Recycling Worldwide : Current Overview and Desirable Changes," The Journal of Field Actions : Field Actions Science Report.

[6] Ellen MacArthur Foundation, Towards the Circular Economy, Ellen MacArthur Foundation, 2013.

[7] M. Joyosuyono, Interviewee, Depth Interview. [Interview]. 2020.

[8] J. Wiganda, Interviewee, Depth Interview. [Interview]. 2020.

[9] H. U. Sudibyo, Interviewee, Depth Interview. [Interview]. 2020.

[10] S. Hemels, "Influence of Different Purposes of Value Added Tax and Personal Income Tax on an Effective and Efficient Use of Tax Incentives: Taking Tax Incentives for the Arts and Culture as an Example," IBDF, 2009.

[11] A. Easson, Tax Incentives for Foreign Direct Investment, Netherlands: Kluwer Law International, 2004.

[12] J. Heller and K. M. Kauffman, Tax Incentives for Industry in Less Developed Countries, Chicago: Commerce Clearing House, Inc., 1963.

[13] Republik Indonesia, Undang-Undang Nomor 42 Tahun 2009 tentang Pajak Pertambahan Nilai Barang dan Jasa dan Pajak Penjualan atas Barang Mewah, Republik Indonesia, 2009.

[14] T. M. Putranti, Interviewee, Depth Interview. [Interview]. 2020.

[15] R. Saputra, Interviewee, Depth Interview. [Interview]. 2020.

[16] OECD, "Extended producer responsibility," [Online]. Available: https://www.oecd.org/env/toolsevaluation/extendedproducerresponsibility.html.

[17] R. Cooper, "97\% of plastic bottles in Norway are recycled," 2018. [Online]. Available: http://www.climateaction.org/news/97-of-plasticbottles-are-recycled-in-norway. 